\title{
KONSTRIBUSI PEMBIAYAAN PERBANKAN SYARIAH TERHADAP PENGEMBANGAN USAHA MIKRO, KECIL, DAN MENENGAH
}

\author{
Muslimin Kara \\ Program Studi Ekonomi Islam UIN Alauddin Makassar \\ Jl. Sultan Alauddin No. 36 Makassar, Sulawesi Selatan \\ E-mail: mushajikara@gmail.com
}

\begin{abstract}
The Contribution of Funding Shariab Banking to Developing Micro, Small, and Medium Enterprises Inority Jurisprudence. The characteristics of Islamic banking are different to conventional banking, because Islamic banking based on the core products of for results which developed into mushârakah and mudârabah financing products. Thus, the existence of Islamic bank should provide large contributions toward real sector development. One enterprise unit that needs to be developed to support real sector development is Micro Small and Medium Enterprises (MSMEs) in the current national economy havinga very important position, because of its contribution in employment and Gross Domestic Product (GDP), as well as flexibility and strength in the face of economic crisis.
\end{abstract}

Keywords: Islamic fund, Micro, Small, and Medium Enterprises (MSMEs)

\begin{abstract}
Abstrak: Konstribusi Pembiayaan Perbankan Syariab terhadap Pengembangan Usaha Mikro, Kecil, dan Menengab. Karakteristik perbankan syariah berbeda dengan perbankan yang berdasarkan sistem bunga, karena perbankan syariah didasarkan pada core product pembiayaan bagi hasil yang dikembangkan dalam produk pembiayaan mushârakah dan mudârabah. Dengan demikian, kehadiran perbankan syariah seharusnya memberikan dampak yang besar terhadap pertumbuhan sektor riil. Salah satu unit usaha yang perlu dikembangkan untuk mendorong pertumbuhan sektor riil adalah usaha mikro kecil dan menengah (UMKM) yang dalam perekonomian nasional saat ini memiliki posisi yang sangat penting, karena kontribusinya dalam penyerapan tenaga kerja dan pendapatan domestik bruto (PDB), serta fleksibilitas dan ketangguhannya dalam menghadapi krisis ekonomi.
\end{abstract}

Kata Kunci: pembiayaan syariah, usaha mikro, kecil, dan menengah (UMKM)

\section{Pendahuluan}

Perbankan merupakan salah satu agen pembangunan (agent of development) dalam kehidupan bernegara, karena fungsi utama dari perbankan adalah sebagai lembaga intermediasi keuangan (financial intermediary institution), yaitu lembaga yang menghimpun dana dari masyarakat dalam bentuk simpanan dan menyalurkannya kembali kepada masyarakat dalam bentuk kredit atau pembiayaan. Fungsi perbankan sebagai lembaga intermediasi keuangan juga menjadi concern dari perbankan syariah, disamping sebagai lembaga yang mengelola zakat, infak, dan sedekah (ZIS).

Eksistensi perbankan syariah di Indonesia mengalami perkembangan yang signifikan setelah diundangkannya Undang-Undang Nomor 10 Tahun 1998 tentang Perubahan atas Undang-Undang Nomor 7 Tahun 1992

Naskah diterima: 20 Februari 2013, direvisi: 17 Mei 2013, disetujui untuk terbit: 24 Mei 2013 tentang Perbankan yang lebih mengakomodasi dan memberi peluang bagi perkembangan perbankan syariah. Kehadiran undang-undang tersebut diperkuat lagi dengan lahirnya Undang-undang Nomor 21 tahun 2008 tentang Perbankan Syariah yang secara tegas mengakui eksistensi dari perbankan syariah dan membedakannya dengan sistem perbankan konvensional.

Pasal 1 ayat (7) Undang-Undang Nomor 21 Tahun 2008 tentang Perbankan Syariah menjelaskan bahwa bank syariah adalah bank yang menjalankan kegiatan usahanya berdasarkan prinsip syariah. Menurut jenisnya, bank syariah terdiri atas Bank Umum Syariah (BUS) dan Bank Pembiayaan Syariah (BPRS). Dalam menjalankan kegiatan usahanya, bank syariah memberikan pembiayaan berdasarkan prinsip bagi hasil (mudârabah), penyertaan modal (mushârakah), jual-beli barang dengan memperoleh keuntungan (murâbahah), sewa murni tanpa pilihan (ijârah), atau dengan adanya pilihan pemindahan kepemilikan atas barang yang 
disewa dari pihak bank oleh pihak lain (ijârah wa iqtinâ), akad salam, akad istithnâ, sewa-menyewa yang diakhiri dengan kepemilikan (ijârah al-muntahiya bi al-tamlîk), dan prinsip lainnya yang tidak bertentangan dengan prinsip syariah. ${ }^{1}$

Melihat ruang lingkup kegiatan usahanya dapat dinyatakan bahwa produk perbankan syariah lebih variatif dibandingkan dengan produk bank konvensional. Hal ini memungkinkan produk bank syariah memberi peluang yang lebih luas dalam rangka memenuhi kebutuhan nasabah deposan maupun debitur sesuai dengan kebutuhan nyata mereka. Khusus dalam hal penyaluran dana kepada masyarakat, maka skema pembiayaannya dapat disesuaikan dengan kebutuhan nasabah. Sementara itu sektor ekonomi di Indonesia secara faktual sebagian besar didukung oleh sektor usaha mikro, kecil, dan menengah (UMKM). Pada saat krisis ekonomi, sektor ini mampu tetap bertahan. Sektor UMKM mempunyai keunggulan dan sangat potensial untuk lebih dikembangkan melalui suatu kebijakan yang tepat dan dukungan dari lembaga yang tepat pula.

Permasalahan utama yang dihadapi oleh sektor UMKM adalah masalah permodalan. Sektor UMKM mengalami kesulitan dalam memperoleh modal dari bank. Salah satu sebabnya adalah tingkat suku bunga kredit yang tinggi dan diharuskan adanya jaminan kebendaan (collateral minded) dalam memperoleh kredit yang sulit dipenuhi. Pemberian fasilitas kredit sebagai aktivitas utama lembaga perbankan pada dasarnya memiliki ciri yang sama sejak dulu. Namun dalam perkembangannya saat ini mengarah pada variasi dan pola-pola yang menggabungkan perkembangan teknologi dengan segmen pasar dan regulasi yang menyertainya. Jika dilihat dari segi pola dan penggolongan kredit, maka salah satu produk perbankan dalam memberikan kreditnya kepada masyarakat adalah melalui UMKM. ${ }^{2}$

Dalam tatanan pembangunan nasional, UMKM adalah bagian integral dunia usaha berupa kegiatan ekonomi rakyat yang kedudukan, potensi, dan peran-

${ }^{1}$ Pasal 19 Undang-Undang Nomor 21 Tahun 2008 tentang Perbankan Syariah.

${ }^{2}$ Pemerintah dan Komisi VI DPR-RI menyepakati Rancangan Undang-Undang (RUU) tentang Usaha Mikro, Kecil, dan Menengah (UMKM) untuk kemudian diperkenalkan sebagai istilah baru pengganti UMKM yang telah ada selama ini. RUU tersebut kemudian disahkan menjadi UU No. 20 Tahun 2008 tentang Usaha Mikro, Kecil, dan Menengah (UMKM). Adanya UU ini memberikan kepastian hukum bagi UMKM untuk mengembangkan usahanya. Sri Adiningsih, "Revitalisasi UMKM", dalam http://www.niriah.com, diunduh pada tanggal 10 Juli 2008. nya sangat strategis untuk mewujudkan struktur perekonomian yang semakin seimbang berdasarkan demokrasi ekonomi. Oleh karena itu maka UMKM ini perlu mendapat perhatian dan perlindungan dari pemerintah. Dalam Undang-Undang No. 20 Tahun 2008 tentang Usaha Mikro Kecil dan Menengah secara tegas telah adanya pendefenisian pemisahaan klasifikasi usaha. Pasal 1 UU Nomor 20 Tahun 2008 menyebutkan bahwa: Pertama, usaha mikro adalah usaha produktif milik orang-perorangan dan/atau badan usaha perorangan yang memenuhi kriteria usaha mikro sebagaimana diatur dalam undang undang. Kedua, usaha kecil adalah usaha ekonomi produktif yang berdiri sendiri dan dilakukan oleh orang-perorangan atau badan usaha yang bukan merupakan anak perusahaan atau bukan cabang perusahaan yang dimiliki, dikuasai, atau menjadi bagian baik langsung maupun tidak langsung dari usaha menengah atau usaha besar yang memenuhi kriteria usaha kecil sebagaimana dimaksud dalam undang undang ini. Ketiga, usaha menengah adalah usaha ekonomi produktif yang berdiri sediri dan dilakukan oleh orang-perorangan atau badan usaha yang bukan merupakan anak perusahaan atau cabang perusahaan yang dimiliki, dikuasai, atau menjadi bagian baik langsung maupun tidak langsung dengan usaha kecil atau usaha besar dengan jumlah kekayaan bersih atau hasil penjualan tahunan sebagaimana diatur dalam undang-undang ini ${ }^{3}$.

Berdasarkan prinsip dasar produk tersebut maka bank syariah sesungguhnya memiliki core product pembiayaan bagi hasil yang dikembangkan dalam produk pembiayaan mushârakah dan mudârabah. ${ }^{4}$ Kehadiran bank syariah seharusnya memberikan dampak yang luar biasa terhadap pertumbuhan sektor riil khususnya UMKM. Hal ini dikarenakan pola mudârabah dan mushârakah merupakan pola investasi langsung pada sektor riil dan return pada sektor keuangan (bagi hasil). Dengan demikian, keberadaan bank syariah harus mampu memberikan kontribusi untuk meningkatkan pertumbuhan sektor riil. Fungsi tersebut akan terwujud apabila bank syariah menggunakan akad profit and loss sharing (mudârabah dan mushârakah) sebagai core product-nya 5 .

${ }^{3}$ Lihat Undang Undang Nomor 20 Tahun 2008 tentang Usaha Mikro, Kecil dan Menengah.

4 Muhammad, "Permasalahan Agency Dalam Pembiayaan Mudharabah Pada Bank Syariah di Indonesia”, Disertasi tidak diterbitkan, (Yogyakarta: UII, 2005), h. 23.

${ }^{5}$ Irfan Syauqi Beik, "Bank Syariah dan Pengembangan Sektor Riil", dalam www.pesantrenvirtual.com, diunduh pada tanggal 10 Juli 2008. 
Dengan semaraknya perkembangan sektor perbankan syariah maka diharapkan dapat membantu perkembangan UMKM secara optimal. Usaha mikro kecil dan menengah pada perekonomian saat ini memiliki posisi yang sangat penting, karena kontribusinya dalam penyerapan tenaga kerja dan Pendapatan Domestik Bruto (PDB), serta fleksibilitas dan ketangguhannya dalam menghadapi krisis ekonomi yang berkepanjangan. Hal ini menjadikan UMKM sebagai harapan utama atau tulang punggung peningkatan perekonomian nasional. UMKM juga merupakan pelaku ekonomi yang strategis mengingat jumlahnya yang mencapai $99,95 \%$ dari total jumlah usaha di Indonesia. Namun perkembangan UMKM masih terkendala masalah kekurangan modal sehingga membutuhkan pembiayaan untuk mendukungnya. Banyak fasilitas kredit yang ditawarkan, baik itu dari bank konvensional, microfinance, dan tidak terkecuali dari bank syariah untuk UMKM. Namun dari semua tawaran skema kredit tersebut, hanya sekira $60 \%$ yang dapat memenuhi kebutuhan UMKM karena mereka belum bisa memanfaatkan tawaran tersebut dengan baik. Salah satu sebab kesulitan UMKM untuk memperoleh kredit/pembiayaan adalah keharusan adanya collateral atau jaminan yang dimiliki ${ }^{6}$.

Kondisi tersebut juga dialami oleh UMKM di Kota Makassar. Pembiayaan yang diberikan oleh bank syariah dengan karakteristik yang berbeda dengan kredit/pinjaman (loan) dari bank konvensional diharapkan UMKM akan dapat memenuhi kebutuhan permodalan dimaksud. Permasalahan yang muncul kaitannya dengan hal ini adalah mengenai jenis pembiayaan apa yang cocok untuk UMKM dan bagaimana sebaiknya bank syariah menyikapi kebutuhan dari UMKM di Kota Makassar. Dengan demikian maka perlu dilakukan penelitian tentang pembiayaan syariah dan pengaruhnya terhadap peningkatan Usaha Mikro Kecil dan Menengah di Kota Makassar.

\section{Kontribusi Pembiayaan Syariah bagi UMKM di Kota Makassar}

Berdasarkan hasil penelitian disebutkan bahwa besarnya pembiayaan syariah untuk sektor-sektor ekonomi dan UMKM oleh perbankan syariah di Kota Makassar selama tahun 2010 sampai dengan September 2011 adalah sebagai berikut:

\footnotetext{
${ }^{6}$ Aswandi 5, "Kiprah UMKM di Tengah Krisis Ekonomi-Perannya Besar, Minim Perhatian Pemerintah", dalam http://www.sme-center. com, 2007, diunduh pada tanggal 02 April 2008.
}

Tabel 1

Besarnya Penyaluran Kredit Sektor Ekonomi dan UMKM oleh Pembiayaan Perbankan Syariah di Kota Makassar Januari-Desember 2010 (Rp Juta)

\begin{tabular}{|c|c|c|c|}
\hline \multirow{2}{*}{ Bulan } & \multicolumn{2}{|c|}{ Pembiayaan Syariah } & \multirow{2}{*}{ Kontribusi } \\
\hline & Sektor Ekonomi & UMKM & \\
\hline Januari & 985,582 & 126,354 & 12,82 \\
\hline Pebruari & $1,054,958$ & 134,491 & 12,74 \\
\hline Maret & $1,116,459$ & 127,714 & 11,43 \\
\hline April & $1,218,590$ & 172,765 & 14,17 \\
\hline Mei & $1,266,177$ & 190,603 & 15,05 \\
\hline Juni & $1,472,198$ & 349,637 & 23,74 \\
\hline Juli & $1,530,724$ & 219,421 & 14,33 \\
\hline Agustus & $1,600,218$ & 237,386 & 14,83 \\
\hline September & $1,678,388$ & 255,750 & 15,23 \\
\hline Oktober & $1,731,223$ & 251,496 & 14,52 \\
\hline Nopember & $1,719,493$ & 186,692 & 10,85 \\
\hline Desember & $1,699,761$ & 187,990 & 11,05 \\
\hline
\end{tabular}

Sumber: Bank Indonesia Makassar Tahun 2011

Tabel 1 memperlihatkan bahwa selama tahun 2010 (Januari-Desember) besarnya pembiayaan syariah yang disalurkan oleh perbankan syariah untuk sektor-sektor ekonomi dan UMKM di Kota Makassar berfluktuasi. Kontribusi terbesar yang diberikan oleh pembiayaan syariah perbankan terjadi pada bulan Juni 2010 yaitu Rp 349.637.000.000 atau 23,74\% dari total kredit yang dikeluarkan oleh perbankan syariah, meskipun disadari bahwa sektor ekonomi masih mendominasi kredit perbankan syariah dibandingkan dengan UMKM. Pada bulan Nopember dan Desember, kontribusi pembiayaan syariah terhadap UMKM hanya 10,85\% dan 11,05\%. Secara rata-rata, kontribusi pembiayaan perbankan syariah terhadap UMKM di Kota Makassar selama tahun 2010 sebesar $14,23 \%$.

Selanjutnya, pada tahun 2011 (Januari-September) besarnya penyaluran kredit oleh pembiayaan perbankan syariah juga berfluktuasi dengan tingkat persentase yang relatif sama yaitu antara 15\%-17\%. Persentase tertinggi terjadi pada bulan Juli dan Agustus masing-masing $17,38 \%$ dan $17,13 \%$. Untuk lebih jelasnya dapat dilihat berikut ini:

Tabel 2

Besarnya Penyaluran Kredit Sektor Ekonomi dan UMKM oleh Pembiayaan Perbankan Syariah di Kota Makassar Januari-September 2011 (Rp Juta)

\begin{tabular}{cccc}
\hline \multirow{2}{*}{ Bulan } & \multicolumn{2}{c}{ Pembiayaan Syariah } & \multirow{2}{*}{ Kontribusi } \\
\cline { 2 - 3 } & Sektor Ekonomi & UMKM & \\
\hline Januari & $1,719,001$ & 276,560 & 16,08 \\
\hline
\end{tabular}




\begin{tabular}{cccc}
\hline Pebruari & $1,847,020$ & 291,156 & 15,76 \\
\hline Maret & $1,951,400$ & 303,096 & 15,53 \\
\hline April & $1,991,688$ & 320,357 & 16,08 \\
\hline Mei & $2,061,793$ & 342,878 & 16,63 \\
\hline Juni & $2,132,583$ & 360,252 & 16,89 \\
\hline Juli & $2,157,774$ & 375,223 & 17,38 \\
\hline Agustus & $2,242,042$ & 384,249 & 17,13 \\
\hline September & $2,285,251$ & 355,900 & 15,57 \\
\hline
\end{tabular}

Sumber: Bank Indonesia Makassar Tahun 2011

Kemudian apabila pembiayaan perbankan syariah di Kota Makassar diperbandingkan dengan Propinsi Sulawesi Selatan, maka secara umum tampak bahwa kredit UMKM yang disalurkan oleh pembiayaan perbankan syariah pada tahun yang sama masih juga menempatkan kredit UMKM hanya rata-rata 15,37\% dibandingkan dengan sektor ekonomi lainnya. Kontribusi terbesar terjadi pada bulan Juni 2010 yaitu 23,88\% dan terendah terjadi pada Nopember 2010 yaitu hanya 11,84\%. Kemudian pada tahun 2011 (JanuariSeptember), secara rata-rata terjadi peningkatan yaitu $18,43 \%$. Untuk lebih jelasnya dapat dilihat pada tabel 3 dan 4 berikut:

Tabel 3

Besarnya Penyaluran Kredit Sektor Ekonomi dan UMKM oleh Pembiayaan Perbankan Syariah Sulawesi Selatan Januari-Desember 2010 (Rp Juta)

\begin{tabular}{cccc}
\hline \multirow{2}{*}{ Bulan } & \multicolumn{2}{c}{ Pembiayaan Syariah } & \\
\cline { 2 - 3 } & $\begin{array}{c}\text { Sektor } \\
\text { Ekonomi }\end{array}$ & UMKM & Kontribusi \\
\hline Januari & $1,176,957$ & 165,270 & 14,04 \\
\hline Pebruari & $1,265,024$ & 186,116 & 14,71 \\
\hline Maret & $1,322,860$ & 180,055 & 13,61 \\
\hline April & $1,437,387$ & 224,772 & 15,63 \\
\hline Mei & $1,484,998$ & 241,665 & 16,27 \\
\hline Juni & $1,699,450$ & 405,842 & 23,88 \\
\hline Juli & $1,768,069$ & 274,523 & 15,52 \\
\hline Agustus & $1,839,709$ & 291,328 & 15,83 \\
\hline September & $1,954,476$ & 311,550 & 15,94 \\
\hline Oktober & $2,015,471$ & 306,431 & 15,20 \\
\hline Nopember & $2,025,116$ & 239,906 & 11,84 \\
\hline Desember & $2,020,185$ & 243,733 & 12,06 \\
\hline
\end{tabular}

Sumber: Bank Indonesia Makassar Tahun 2011
Tabel 4

Besarnya Penyaluran Kredit Sektor Ekonomi dan UMKM oleh Pembiayaan Perbankan Syariah Sulawesi Selatan Januari-September 2011 (Rp Juta)

\begin{tabular}{cccc}
\hline \multirow{2}{*}{ Bulan } & \multicolumn{2}{c}{ Pembiayaan Syariah } & \multirow{2}{*}{ Kontribusi } \\
\cline { 2 - 3 } & Sektor Ekonomi & UMKM & \\
\hline Januari & $2,063,958$ & 348,854 & 16,90 \\
\hline Pebruari & $2,215,304$ & 369,761 & 16,69 \\
\hline Maret & $2,357,987$ & 402,986 & 17,09 \\
\hline April & $2,437,837$ & 439,202 & 18,01 \\
\hline Mei & $2,540,078$ & 479,659 & 18,88 \\
\hline Juni & $2,656,380$ & 520,068 & 19,57 \\
\hline Juli & $2,711,433$ & 542,116 & 19,99 \\
\hline Agustus & $2,813,820$ & 562,560 & 19,99 \\
\hline September & $2,876,478$ & 540,835 & 18,80 \\
\hline
\end{tabular}

Sumber: Bank Indonesia Makassar Tahun 2011

Berdasarkan tabel 1-4 di atas tampak bahwa perhatian perbankan khususnya pembiayaan perbankan syariah terhadap pengembangan UMKM di Kota Makassar semakin tinggi. Dengan demikian keseriusan pembiayaan perbankan syariah di Kota Makassar untuk ikut mendukung peningkatkan kinerja UMKM sudah memperlihatkan hasil yang cukup signifikan. Keberpihakan bank syariah pada sektor UMKM ditunjukkan pula dengan pelbagai strategi pembiayaan oleh masing-masing bank syariah secara individu, seperti pembukaan pusat-pusat pelayanan pembiayaan mikro, gerai UMKM, atau sentra UMKM. Berdasarkan data pembiayaan sektoralnya, saat ini pembiayaan UMKM perbankan syariah di Kota Makassar terkonsentrasi pada pembiayaan di sektor retail $(31,1 \%)$, jasa usaha $(29,3 \%)$, dan perdagangan (13,2\%). Eksposur pembiayaan sektoral UMKM perbankan syariah identik atau sama dengan eksposur total pembiayaan industri.

Meskipun kontribusi perkembangannya cukup besar, namun pertumbuhan sektor UMKM di Kota Makassar memiliki masalah. Masalah dalam sektor UMKM di Kota Makassar sama dengan masalah UMKM secara nasional yang begitu kompleks, mulai dari masalah Sumber Daya Manusia (SDM), akses modal, budaya usaha, tingkat penguasaan teknologi maupun kemampuan manajemen. Sudah menjadi pengetahuan umum bahwa tingkat pendidikan mayoritas pelaku usaha UMKM cukup rendah, budaya usaha yang belum terbangun karena banyak usaha yang dilakukan berdasarkan usaha turun temurun, pengelolaan dana usaha yang bercampur dengan keuangan rumah tangga 
dan lain sebagainya. Beberapa hal ini sedang dibenahi oleh pihak-pihak terkait secara berkesinambungan. Khusus untuk mengatasi masalah akses modal di sektor UMKM, saat ini bank syariah telah melakukan kerja sama dalam penyaluran pembiayaan ke sektor tersebut. Kerjasama tersebut berupa kerjasama pembiayaan yang menggunakan konsep linkage, dimana bank syariah yang lebih besar menyalurkan pembiayaan UMKMnya melalui lembaga keuangan syariah yang lebih kecil, seperti BPRS dan BMT. Hal ini dilakukan karena jangkauan bank syariah besar yang belum menjangkau pelosok-pelosok sentra masyarakat usaha kecil atau lembaga keuangan syariah yang kecil lebih menyentuh langsung dengan pelaku usaha UMKM.

Skema pembiayaan linkage yang dilakukan bank syariah dengan BPRS atau BMT dapat berupa channeling, executing atau joint financing. Skema channeling menempatkan BPRS atau BMT sebagai intermediator Bank Umum Syariah (BUS)/Unit Usaha Syariah (UUS) dengan pelaku UMKM. Sedangkan skema executing dilakukan ketika BUS/UUS menyediakan pendanaan yang dapat dimanfaatkan oleh BPRS atau BMT dalam pembiayaan mereka ke nasabah UMKM-nya. Adapun skema joint financing adalah skema dimana BUS/UUS dan BPRS/BMT bekerja sama dalam memberikan pembiayaan kepada para pelaku UMKM. Disamping itu, saat ini juga terjalin kerja sama beberapa bank syariah dengan lembaga-lembaga terkait dalam memecahkan masalah lain yang dianggap menghambat perkembangan sektor UMKM, seperti masalah budaya usaha, tingkat penguasaan teknologi, dan kemampuan manajemen. Bank syariah bekerja sama dengan lembaga-lembaga pendidikan atau pengelola dana sosial dalam upaya meningkatkan budaya kerja, kemampuan manajemen UMKM, dan penguasaan teknologi. Hal tersebut dilakukan dalam bentuk program-program pembinaan nasabah. Pembinaan nasabah, khususnya bagi nasabah UMKM, menjadi faktor yang krusial dalam menciptakan dan menjaga pembiayaan UMKM yang berkualitas baik.

Pada masa yang akan datang diharapkan lebih banyak pihak mampu memberikan kontribusinya yang signifikan dalam mendorong peran perbankan syariah di sektor UMKM. Di sisi lain, sektor UMKM memerlukan upaya perbaikan sarana atau infrastruktur, baik berupa infrastruktur yang bersifat fisik maupun non-fisik, agar mampu berproduksi dan berkinerja secara efisien. Perbaikan atau pembenahan sektor UMKM diharapkan mampu menekan persepsi risiko tinggi yang melekat pada sektor tersebut. Sedangkan pada sisi perbankan syariah diperlukan adanya pe- ningkatan pengetahuan dan keahlian bankir syariah dalam dunia UMKM di semua sektornya. Dengan begitu maka diharapkan kontribusi perbankan syariah dapat lebih maksimal, misalnya pembiayaan perbankan syariah tidak hanya terkonsentrasi pada sektor retail, jasa usaha, dan perdagangan saja, akan tetapi juga sektor potensial lainnya, khususnya sektor produktif seperti pertanian dan manufaktur.

Berdasarkan hasil wawancara terhadap salah seorang pelaku usaha kecil diperoleh keterangan bahwa dalam rangka penyaluran pembiayaan terhadap UMKM, bank syariah bekerja sama dengan unit manajemen lain seperti BPRS atau koperasi. Hal ini dilakukan oleh bank karena masih memiliki kelemahan-kelemahan yang harus diperhitungkan agar tidak berpengaruh negatif terhadap keuntungan bank.

Hal ini wajar diperhitungkan oleh bank syariah karena secara prinsip pembiayaan bank syariah harus memenuhi dua aspek, yaitu aspek syariah dan ekonomi. Selain harus sesuai syariah, bank syariah juga harus tetap memperhitungkan profitabilitas dari usaha yang akan dibiayai agar menguntungkan bagi bank maupun nasabah. Namun hal ini bukan berarti bahwa bank syariah tidak berpihak pada UMKM, karena bank telah memiliki kebijakan-kebijakan tertentu yang juga merupakan strategi bank dalam menjalankan fungsinya secara optimal.

Bank syariah tidak mau terjebak dalam pola-pola konvensional yang hanya terfokus pada peningkatan profit tanpa melihat aspek-aspek lain seperti aspek keadilan dan keseimbangan. Telah banyak upaya-upaya yang dilakukan oleh bank syariah dalam usaha pengembangan UMKM melalui pembiayaan, diantaranya program linkage yang dilakukan oleh Bank Sulselbar Syariah di Kota Makassar. Hal ini merupakan salah satu kebijakan bank yang baik dalam rangka mengoptimalkan fungsi bank. Bank syariah telah berupaya untuk mengembangkan sektor UMKM melalui pembiayaan. Selain itu juga tercermin dalam kebijakan yang senantiasa mengakomodir kesulitan serta kelemahan UMKM dengan membuat kebijakan-kebijakan yang berpihak pada UMKM. Jumlah pembiayaan yang disalurkan bank syariah untuk sektor UMKM menjadi salah satu indikatornya.

Berdasarkan pemaparan di atas maka dapat dilakukan analisis peran strategis bank syariah dalam pembiayaan proyek UMKM yaitu bahwa sesuai dengan fokus pengembangan perbankan syariah nasional pada fase kedua yaitu meningkatkan kompetensi skill, profesional lembaga, dan pelaku perbankan syariah, serta meningkatkan fungsi intermediasi, efisiensi, dan 
daya saing industri perbankan syariah, maka diperlukan adanya kesiapan menyongsong pasar retail yang masih terbuka peluangnya. Lalu pertanyaannya, haruskah bank syariah terjun langsung dalam mengakomodasi proyek pembiayaan pada sektor tersebut?. Sementara Bank Indonesia (BI) yang berstatus sebagai otoritas moneter menetapkan prosedur agunan yang selama ini masih menyulitkan UMKM untuk masuk dalam LKM formal. Dengan melihat trend pasar yang menjanjikan serta kebijakan BI di awal tahun 2006, bank syariah sebenarnya bisa memasuki pasar UMKM secara langsung, disamping juga tetap mengakomodasi kelas lower dengan program linkage. Masalah kesulitan agunan bisa disiasati dengan mengembangkan social capital berupa pemberdayaan kelompok usaha dan kelompok swadaya masyarakat sehingga berlaku tanggung jawab renteng dengan double pressure yaitu pada bank dan kelompoknya. Oleh karena itu perlu adanya lembaga intermediasi syariah dengan kekuatan sama yang masuk dalam sektor UMKM untuk melindungi kepentingan pengusaha kecil dari praktikpraktik perbankan yang tidak fair dan tidak memenuhi prinsip syariah. Program kredit atau pembiayaan proyek untuk kegiatan produktif seharusnya mencapai sasaran untuk meningkatkan volume produksi yang akan meningkatkan produktivitas di sektor riil sehingga menghasilkan multiplier effect (permintaan tenaga kerja maupun usaha ikutannya) bagi lingkungan sekiranya dan mampu menggerakkan pertumbuhan ekonomi. Dengan demikian diperlukan adanya integrasi program kredit yang tidak bertumpu pada satu lembaga saja.

Sementara itu ada beberapa kendala dan tantangan yang muncul dari perbankan syariah di Kota Makassar. Pertama, relatif kecilnya pangsa perbankan syariah; Kedua, keterbatasan sumber daya manusia yang kapabel; Ketiga, paradigma bank konvensional yang masih kuat. Keempat, masih dikejar target BEP; Kelima, kurang sosialisasi; dan keenam, keterbatasan jaringan.

Adapun kendala yang bersifat kebijakan lebih diakibatkan oleh sejumlah perbedaan dalam pelaksanaan operasional antara bank syariah dan bank konvensional sehingga diperlukan peran yang lebih maksimal dari policy maker. Beberapa ketentuan yang masih perlu diperhatikan di antaranya: Pertama, aturan tentang instrumen terkait masalah likuiditas; Kedua, instrumen moneter yang sesuai dengan prinsip syariah untuk keperluan pelaksanaan tugas bank sentral; Ketiga, standar akuntansi, audit, dan pelaporan; Keempat, ketentuan yang mengatur mengenai prinsip kehati-hatian dan sabagainya. Selain itu juga diperlukan optimalisasi dukungan untuk penerapan dual banking system yang masih jauh dari harapan.

\section{Kendala Pembiayaan Syariah dalam Pengembangan UMKM}

Walaupun bank syariah memiliki pelbagai kelebihan dan keunggulan dalam menggerakkan perekonomian, khususnya sektor UMKM, namun perlu diketahui bahwa pengaruh bank syariah terhadap pertumbuhan perekonomian nasional hanya $0,23 \%$ atau kurang dari $1 \%$. Menurut analisis dari Bank Indonesia bahwa bank syariah akan bisa memengaruhi perekonomian nasional bahkan bisa memengaruhi inflasi jika peran bank syariah dalam pertumbuhan perekonomian nasional berkisar antara 10\%-20\%. Dalam sektor UMKM, yang merupakan salah satu stimulator perekonomian, peran pembiayaan syariah saat ini belum maksimal. Saat ini penyaluran pembiayaan pada sektor UMKM di Kota Makassar masih didominasi oleh bank konvensional.

Adapun alasan-alasan yang menghambat bank syariah dalam mengoptimalkan perannya pada sektor UMKM di Kota Makassar adalah: Pertama, ketersediaan sumber daya manusia yang memahami aspek fikih sekaligus aspek finansial masih sangat terbatas (SDM yang kurang berkualitas). Keduan, kurangnya sosialisasi tentang bank syariah terutama kepada masyarakat lapisan bawah sebagai pemegang peranan penting sektor UMKM. Ketiga, bank syariah kurang aktif dalam pembiayaan. Keempat, kecanggihan teknologi informasi yang masih ketinggalan jika dibandingkan dengan bank konvensional. Kelima, kebijakan pemerintah terhadap perkembangan bank syariah dinilai masih lamban karena pemerintah sendiri masih berpihak pada perbankan konvensional dengan alasan eksistensi bank konvensional selama ini berpengaruh pada perekonomian nasional serta kurangnya pengetahuan pemerintah tentang banksyariah. Keenam, adanya asymetris information atau informasi satu arah antara bank syariah dengan nasabah sehingga tidak ada sinkronisasi dalam menjalankan aktivitasnya. Ketujuh, kadang-kadang terjadi penyelewengan tugas oleh pihak bank syariah karena sumber daya manusia yang diberdayakan berasal dari bank konvensional atau keterbatasan pengetahuan tentang syariah. Kedelapan, peran bank syariah sebagai mitra kerja sektor UMKM yang dinilai belum tuntas, yaitu bank syariah hanya membantu dalam hal pembiayaan dana saja tetapi belum turut serta membantu untuk memajukan UMKM dalam meningkatkan pendapatan. Kesembilan, jumlah bank syariah yang masih terbatas merupakan hambatan yang 
cukup signifikan karena sebagian besar sektor UMKM berlokasi di wilayah pedesaan.

Hambatan-hambatan seperti itulah yang menyebabkan perkembangan bank syariah terhambat walaupun secara teoretis bank syariah memiliki keunggulan kompetitif (competitive advantage) dalam perekonomian nasional. Oleh sebab itu, diperlukan adanya kerjasama antara pemerintah sebagai penentu kebijakan, bank syariah, serta masyarakat. Dengan begitu pembiayaan syariah diharapkan akan mampu bersaing dengan bank konvensional serta memengaruhi pertumbuhan ekonomi nasional melalui pertumbuhan sektor riil.

Usaha kecil dan menengah dalam perekonomian saat ini menempati posisi yang sangat strategis karena kontribusinya dalam penyerapan tenaga kerja dan Pendapatan Domestik Regional Bruto (PDB) Kota Makassar, serta fleksibilitas dan ketangguhannya dalam menghadapi krisis ekonomi yang berkepanjangan. Hal ini menjadikan UMKM sebagai harapan utama atau tulang punggung peningkatan perekonomian daerah maupun nasional di masa mendatang. Namun banyak UMKM yang dalam perkembangannya masih mempunyai keterbatasan dalam modal sehingga perlu pembiayaan untuk mendukung perkembangan tersebut. Banyak fasilitas kredit yang ditawarkan, baik dari bank konvensional, microfinance, dan bank syariah. Namun, dari semua tawaran skema kredit tersebut hanya sekira $60 \%$ yang dapat memenuhi kebutuhan UMKM karena mereka belum bisa memanfaatkannya dengan baik. Hal ini disebabkan oleh adanya beberapa keterbatasan dari UMKM untuk memperoleh pembiayaan bank syariah, salah satunya adalah collateral atau jaminan yang dimiliki.

Ketersediaan jaminan merupakan salah satu hambatan bagi UMKM dalam mengajukan pembiayaan, sebab sebagian besar UMKM tidak memiliki jaminan yang cukup untuk memenuhi persyaratan pengajuan pembiayaan tersebut. Bank biasanya tidak dapat memberikan pembiayaan kepada orang yang tidak memiliki jaminan yang cukup.

Hambatan lain bagi UMKM dalam memperoleh pembiayaan dari bank syariah adalah masih minimnya aspek legalitas dan administrasi. Sebagian besar UMKM tidak memiliki administrasi yang teratur bahkan banyak yang mengalami permasalahan dalam arus kasnya. Mereka menganggap bahwa sistem bagi hasil yang ditawarkan oleh bank syariah terlalu rumit karena setiap bulan mereka harus menghitung berapa persen laba yang harus disetorkan kepada bank. Padahal masih banyak hal yang harus dilakukan oleh pemilik
UMKM mengingat sebagian besar dari UMKM hanya ditangani oleh satu orang. Hal ini berbeda dengan bank konvensional yang menerapkan sistem bunga. Mereka tidak kesulitan untuk menghitung kembali besar bagi hasil yang harus dibayarkan setiap bulan, karena besar angsuran yang mereka bayar sudah ditetapkan pada awal perjanjian utang dengan jumlah tetap setiap bulannya.

Selain itu, pemerataan pembiayaan bank syariah ke semua wilayah masih kurang dan pengetahuan masyarakat mengenai sistem bank syariah masih minim. Di kota-kota kecil, masyarakat setempat hanya sedikit yang benar-benar mengetahui tentang sistem dan kelebihan pembiayaan bank syariah. Kebanyakan dari mereka hanya mengetahui bahwa bank syariah itu hanya bank yang menabungnya di kantor pos dan tidak berfikir untuk mengajukan pembiayaan. Hal itu tidak terlepas dari keterbatasan bank syariah di daerah tersebut, sehingga kebanyakan UMKM masih terfokus pada pembiayaan konvesional yang menggunakan sistem bunga.

Penetapan harga produk bank syariah yang kadang lebih tinggi dari bank konvensional juga mempunyai pengaruh pada kurangnya minat masyarakat dalam mengakses produk bank syariah, karena harga tersebut relatif memberatkan pelaku UMKM, apalagi yang memiliki pendapatan relatif kecil. Saat ini banyak bank konvensional yang menawarkan kredit dengan bunga kecil kepada UMKM. Hal itu tidak terlepas dari dominasi bank-bank konvensional karena dari segi umur bank konvensional lebih dikenal oleh masyarakat dari pada bank syariah.

Oleh karena itu maka perlu adanya solusi untuk mempermudah akses UMKM terhadap pembiayaan bank syariah. Semua pihak harus berperan dalam hal ini, baik pemerintah, bank syariah, dan UMKM sendiri. Bankbank syariah diharapkan dapat lebih memperluas akses dan mensosialisasikan kelebihannya dengan baik sehingga bank syariah bisa menjadi penguat dan pendamping pengembangan UMKM. Sementara pemerintah dapat memberikan fasilitas pelatihan manajemen bagi para pelaku UMKM agar kompetensi mengenai pengelolaan administrasi usaha dapat meningkat.

\section{Penutup}

Perkembangan pembiayaan perbankan syariah dalam upaya pengembangan UMKM di Kota Makassar selama tahun 2010-2011 mengalami peningkatan yang berfluktuasi. Hal tersebut mencerminkan bahwa peran serta pembiayaan perbankan syariah dalam peningkatan UMKM di Kota Makassar belum optimal. Secara rata-rata perkembangan pembiayaan perbankan 
syariah selama periode Januari-Desember 2010 sebesar $14,23 \%$, sedangkan periode Januari-September tahun 2011 sebesar 18,43\%. Meskipun besarnya pembiayaan perbankan syariah yang disalurkan oleh bank syariah di Kota Makassar berfluktuasi namun secara umum tetap memiliki prospek yang cukup signifikan. Kontribusi pembiayaan perbankan syariah dalam upaya pengembangan UMKM di Kota Makassar sangat dibutuhkan karena masih banyak UMKM yang selama ini belum memperoleh fasilitas pembiayaan. Sedangkan kendala dan tantangan yang selama ini banyak dihadapi oleh perbankan syariah di Kota Makassar dalam upaya pengembangan UMKM adalah keterbatasan pangsa pasar perbankan syariah dan sumber daya manusia yang kapabel, paradigma bank konvensional yang masih kuat, masih dikejar target BEP, kurangnya sosialisasi, dan masih terbatasnya jaringan.[]

\section{Pustaka Acuan \\ Buku/Makalah/Artikel:}

Akhbar, Burhan, "Sinergisme Konsep Corporate Governance dan Konsep Distribusi Nila Tambah Dalam Upaya Meminimalisasi Permasalahan Agensi Pada Pembiayaan Mudharabah", makalah disampaikan pada LKTI Temu Ilmiah Nasional Universitas Jenderal Soedirman tahun 2006.

Arifin, Zainul, Dasar-Dasar Manajemen Bank Syariah, Jakarta: Alvabeth, 2002.

--------, Memahami Bank Syariah Lingkup, Peluang, Tantangan dan Prospek, Jakarta: Alvabet, 1999.

Ashshiddiqi, T.M.Hasbi, Alquran dan Terjemahannya, Jakarta: PT. RadjaGrafindo Persada, t.th.

Aswandi S, "Kiprah UMKM di Tengah Krisis EkonomPerannya Besar, Minim Perhatian Pemerintah", dalam http://www.sme-center.com, diunduh pada tanggal 02 April 2008.

Bank Indonesia, Laporan Perkembangan Perbankan Syariah Tahun 2009, Jakarta: Direktorat Perbankan Syariah, 2010.

Bastian Bustami. et al., eds., Mari Membangun Usaha Mandiri, cet. II, Yogyakarta: Graha Ilmu, 2007.

Beik, Irfan Syauqi, "Bank Syariah dan Pengembangan Sektor Riil”, dalam www.pesantrenvirtual.com, diunduh pada 10 Juli 2008.

Diana Yumanita, Ascarya, Mencari Solusi Rendahya Pembiayaan Bagi Hasil di Perbankan Syariah Indonesia, Jakarta: Bank Indonesia, 2005.

Imaduddin, Muhammad, "Bank Syariah Sang Enterpreneur", dalam www.pesantrenvirutal.com, diunduh pada tanggal 10 Juli 2008.
------, "Mudârabah dan Optimalisasi Sektor Riil", dalam www.republika.co.id, diunduh pada tanggal 12 Juli 2008.

Isono, Sadoko. et al., eds, Pengembangan Usaha Kecil Pemihakan Setengah Hati, cet. I, Bandung: Akatiga, 1995.

Kiryanto, Ryan, "Sistem syariah lebih cocok untuk pembiayaan UMKM", dalam www.bisnis.com.

Muhammad, Manajemen Bank Syariah Edisi Revisi, Yogyakarta: Unit Penerbit dan Percetakan (UPP) AMP YKPN, 2005.

---------, Permasalahan Agency Dalam Pembiayaan Mudharabah Pada Bank Syariah di Indonesia, Disertasi, Yogyakarta: UII Press, 2005.

Musa, Hubeis, Prospek Usaha Kecil dalam Wadah Inkubator Bisnis, Cet.I, Bogor: Galia Indonesia, 2009.

Nizarul, Alim, Pembiayaan Syariah untuk Usaha Mikro dan Kecil: Studi Kasus dan Solusi, Cet. I, Surabaya: PT. Bina Ilmu, 2009.

Partahian Lase, Risanto, Laporan Pengenalan Bisnis PT Bank Mandiri, Yogyakarta: UKI Yogyakarta, 2006.

Singgih, Wibowa, Petunjuk Mendirikan Usaha Kecil, cet. VII, Jakarta: Penebar Swadaya, 1995.

Soeharto, Prawirokusumo, Kewirausahaan dan Manajemen Usaha Kecil, cet. I, Yogyakarta: BPFE Yogyakarta, 2000.

Sugema, Iman, "Islamic Banking: The Fact and Challenges", makalah disampaikan dalam Forum Studi Islam FE UI ke-13 di Jakarta tahun 2007.

Sumaryanto, Mengenal Kewirausahaan, cet. I, Semarang: PT. Sindur Press, 2010.

Sumiyanto, Ahmad, Problem dan Solusi Transaksi Muharabah, Yogyakarta: Magistra Insania Press, 2005.

Warkum, Sumitro, Azas-Azas Perbankan Islam dan Lembaga-Lembaga Terkait, Jakarta: RajaGrafindo Persada, 2004.

Zuhdi, Ramzi, "Berebut Triliunan Rupiah di Syariah", dalam Majalah Tempo edisi 21 Oktober 2007.

\section{Perundang-undangan:}

Undang-Undang Nomor 19 Tahun 2003 tentang Badan Usaha Milik Negara.

Undang-Undang Nomor 20 Tahun 2008 tentang Usaha Mikro, Kecil, dan Menengah.

Undang-Undang Nomor 21 Tahun 2008 tentang Perbankan Syariah.

Undang-Undang Nomor 9 Tahun 1995 tentang Usaha Kecil dan Menengah.

Undang-Undang Nomor 10 Tahun 1998 tentang Perubahan atas Undang-Undang Nomor 7 Tahun 1992 tentang Perbankan. 